\title{
Theoretical Challenges to Practical Specialised Lexicography*
}

\author{
Sven Tarp, Centre for Lexicography, Aarhus School of Business, Aarhus, \\ Denmark
}

\begin{abstract}
During the last decades, part of lexicography has developed into an independent science with an elaborated system of theories based on the users' needs and corresponding dictionary functions. This also applies to specialised lexicography. Many lexicographers, however, still refuse to view their discipline as an independent science and treat it as a subdiscipline, i.e. of linguistics, or they consider specialised lexicography as something different from lexicography in general (which is the case with part of the so-called terminographers). Both interpretations have unfortunate consequences for lexicographic theory and practice. The great challenge now is to strengthen lexicography as a science, and to apply its system of scientific theories to the practical planning and compilation of specialised dictionaries. A look at existing dictionaries shows that there is still a lot of work to be done. Due to economic, editorial and other limitations, a great deal of pragmatism is often practised when compiling a concrete specialised dictionary. Lexicographic pragmatism might be necessary, but in order to be successful it must be guided by theory.
\end{abstract}

Keywords: COMMUNICATION-ORIENTATED FUNCTION, CULTURAL INFORMATION, DICTIONARY, ENCYCLOPAEDIA, ENCYCLOPAEDIC INFORMATION, GENUINE PURPOSE OF A DICTIONARY, GRAMMATICAL INFORMATION, KNOWLEDGE-ORIENTATED FUNCTION, LEXICOGRAPHIC FUNCTION, LEXICOGRAPHIC PRAGMATISM, LEXICOGRAPHIC SKILLS, LEXICOGRAPHY, LINGUISTIC SKILLS, LSP DICTIONARY, LSP LEXICOGRAPHY, PRACTICAL LEXICOGRAPHY, SEMANTIC INFORMATION, SPECIALISED DICTIONARY, SPECIALISED LEXICOGRAPHY, SUBJECT-FIELD SKILLS, TERMINOGRAPHY, TERMINOLOGY, THEORETICAL LEXICOGRAPHY, USER CHARACTERISTICS, USER NEEDS, USER SITUATIONS, USER-ORIENTATED LEXICOGRAPHY

Opsomming: Teoretiese uitdagings vir die praktiese gespesialiseerde leksikografie. Gedurende die laaste dekades het 'n deel van die leksikografie in 'n onafhanklike wetenskap ontwikkel met 'n uitvoerige stelsel van teorieë gebaseer op gebruikersbehoeftes en korresponderende woordeboekfunksies. Dit is ook van toepassing op die gespesialiseerde leksikografie. Baie leksikograwe weier egter steeds om hulle dissipline as 'n onafhanklike wetenskap te sien en hanteer dit as 'n subdissipline, d.w.s. van die linguistiek, of hulle beskou gespesialiseerde leksikografie as iets anders as algemene leksikografie (wat die geval is met 'n deel van die sogenaamde terminograwe). Albei interpretasies het ongelukkige gevolge vir die leksikografiese teorie en prak-

* This paper was presented as a keynote address at the Fifth International Conference of the African Association for Lexicography, held at the University of Stellenbosch, Stellenbosch, 35 July 2000. 
tyk. Die groot uitdaging is nou om die leksikografie as 'n wetenskap te konsolideer, en om sy stelsel van wetenskaplike teorieë op die praktiese beplanning en samestelling van gespesialiseerde woordeboeke toe te pas. 'n Kykie na bestaande woordeboeke wys dat daar nog baie werk is wat gedoen moet word. Weens ekonomiese, redaksionele en ander beperkings word ' $n$ groot mate van pragmatisme toegepas wanneer 'n konkrete gespesialiseerde woordeboek saamgestel word. Leksikografiese pragmatisme mag nodig wees, maar om suksesvol te wees moet dit deur teorie gelei word.

Sleutelwoorde: KOMMUNIKASIE-GEÖRIËNTEERDE FUNKSIE, KULTURELE INLIGTING, WOORDEBOEK, ENSIKLOPEDIE, ENSIKLOPEDIESE INLIGTING, WARE DOEL VAN 'N WOORDEBOEK, GRAMMATIESE INLIGTING, KENNIS-GEÖRIËNTEERDE FUNKSIE, LEKSIKOGRAFIESE FUNKSIE, LEKSIKOGRAFIESE PRAGMATISME, LEKSIKOGRAFIESE VAARDIGHEDE, LEKSIKOGRAFIE, TAALKUNDIGE VAARDIGHEDE, TSD-WOORDEBOEK, TSD-LEKSIKOGRAFIE, PRAKTIESE LEKSIKOGRAFIE, SEMANTIESE INLIGTING, GESPESIALISEERDE WOORDEBOEK, GESPESIALISEERDE LEKSIKOGRAFIE, VAKGEBIEDVAARDIGHEDE, TERMINOGRAFIE, TERMINOLOGIE, TEORETIESE LEKSIKOGRAFIE, GEBRUIKERSEIENSKAPPE, GEBRUIKERSBEHOEFTES, GEBRUIKERSITUASIES, GEBRUIKER-GEÖRIËNTEERDE LEKSIKOGRAFIE

\section{Introduction}

Is lexicography a subdiscipline of linguistics? No, it is not. Although I would have preferred that many dictionaries, due to their poor quality, were considered products of linguistics and not lexicography.

Is terminography different from lexicography? No, it is not. Although I would have preferred that it was so due to the poor quality of a large number of terminographical products.

It is, of course, not my intention to offend anybody personally. In fact, I respect the efforts made by lexicographers or terminographers who produced the works which I criticise. But at the same time, I believe that it is my duty as a lexicographer who considers his discipline to be a scientific discipline, to be frank. The truth is that a large number of dictionaries, and especially LSP dictionaries as they are unfortunately called, do not live up to the standards of modern lexicographic works. And the truth is also that one of the reasons for this situation, if not the main reason, is that lexicography is not viewed as an independent science with its own independent system of lexicographic theories and its own independent lexicographic practice. This is the purpose of my paper, i.e. to argue that lexicography in general and specialised lexicography in particular, inclusive of terminography, must be viewed as an independent science. Only on this scientific basis will it be possible to raise the standard of lexicographic works immediately and produce the large number of high quality dictionaries needed in the present era of globalisation. 


\section{Lexicography and linguistics}

Although the first dictionaries produced in China and India several thousand years ago were specialised dictionaries, during the last centuries it has mainly been academics with a linguistic background who have made the so-called LGP dictionaries. This is quite understandable because there is a growing need of a description and standardisation of the national languages and the creation of tools to facilitate bilingual communication.

However, this situation has had a number of negative consequences for lexicographic theory and practice. Many linguists have transferred their own theoretical instrumentarium to lexicography. In this way, they have been considering lexicography to be a subdiscipline of linguistics (see figure 1). This has meant that their analysis and studies of lexicography genetically were unable to go right to the root of lexicography and to discover its very essence. So all their studies of lexicography, which from the point of view of linguistics may be very scientific, leave much to be desired from the point of view of modern lexicography and are, as such, mostly very superficial.

Figure 1: The linguistic approach to lexicography: Lexicography as a subdiscipline of linguistics

But is it not correct to view lexicography as a subdiscipline of linguistics? Is it not correct that dictionaries - as Landau (1984) once said - are about words, which are one of the basic subjects of linguistic study, and that dictionaries and lexicography must thus be considered a subdiscipline of linguistics? No, it is not. The following article from a specialised dictionary will clearly show this:

gastrulation During early embryogenesis, the invagination and reshaping of the cells of the blastoderm that results in differentiation into ectoderm, endoderm and mesoderm.

Text example 1: Dictionary article from Glick (1997) 
Here we have an article from a dictionary that is conceived for people who have interest in learning more about biochemistry and molecular biology. Of course, the entry is a word and the explanation - or definition if you wish is composed of words. But if this should be sufficient to make this dictionary a subproduct of linguistics, then every science in this world would be a subdiscipline of linguistics, because all sciences have to use words and language in order to express themselves. And this is absurd. In fact, if you can speak, write and spell English correctly, no special linguistic knowledge is needed to conceive and produce the above-mentioned dictionary. On the contrary, a profound knowledge of biochemistry and molecular biology is absolutely necessary to write the quoted explanation. So, if you should follow the logic of those who are normally claiming that lexicography is a subdiscipline of linguistics, in the particular case of the above-mentioned dictionary, this dictionary should be considered a subproduct of biochemistry and molecular biology. And the logical conclusion would be that at least this part of lexicography, i.e. biochemical and molecular biological specialised lexicography, should be viewed as a subdiscipline of biochemistry and molecular biology. And this is also absurd, because then lexicography would be something very schizophrenic: at the same time a subdiscipline of a large number of different and independent scientific disciplines (see figure 2).

Figure 2: The schizophrenic model of lexicography: Lexicography viewed as a subdiscipline of linguistics, genetics, etc.

I think that the growing interest in specialised lexicography is making it quite clear that you cannot consider lexicography to be a subdiscipline of linguistics as many so-called LGP lexicographers have done due to their own linguistic background. The only solution is to view lexicography as an independent science, just like linguistics, genetics, biochemistry, molecular biology, etc. All of them are constituted by an independent set of knowledge elements, but at the same time they include a number of subsets of knowledge elements which they have in common with other disciplines.

In this way, linguistics and lexicography must be viewed as two independent disciplines where linguists sometimes - but only sometimes - make 
use of lexicography for their work and where lexicographers sometimes make use of linguistics for their theoretical and practical work. This relation is shown schematically in figure 3:

Figure 3: The modern lexicographic concept of lexicography: Linguistics and lexicography as independent disciplines with a subset of common elements

\section{An independent science}

Every independent science has its own basis and subject field: the subject of linguistics is language, the subject of biology is life, the subject of genetics is genes and their constituents, etc. What then is the subject of lexicography? It is dictionaries, or to be more specific: lexicographic reference works. It is of course true that these works need knowledge about language, biology and genetics in order to fulfil their objectives. But this only shows that in its very essence, lexicography is an open science with a great interdisciplinary vocation.

Genes and life are preconditions for the existence of human beings. And language is a property without which man would not be man. Lexicographic reference works, however, are human-made products. And as any other product of this sort, they are produced in order to satisfy certain human needs. That is why Wiegand (1988) called lexicographic reference works utility products that are produced for a specific purpose. In this connection, Wiegand introduces the concept of the "genuine purpose" of dictionaries in opposition to their "nongenuine purpose" - for example to kill the neighbour's cat with a heavy Webster. The genuine purpose of a lexicographic reference work is, according to Wiegand, "that it can be used to obtain information from its lexicographic data about the respective subject of the reference work (daß sie benutzt werden können, um aus ihren lexikographischen Daten Informationen über den jeweiligen Gegenstand der Nachschlagewerk zu gewinnen)".

This definition is, in my opinion, very precise, although it is (and of course must be) of a very general character. Wiegand (1988) himself tries to make a 
more detailed typology of different kinds of dictionaries based on a distinction between semantics and encyclopaedics, but more about that later on.

\section{Lexicography and terminology}

Terminography is normally viewed as a subdiscipline of terminology. What is the subject field of terminology? Although there has been given many definitions of terminology, I have not succeeded in finding any exact definition answering this question. However, a qualified suggestion would be the registration and organisation of knowledge in general. If this is the case, terminology clearly distinguishes itself from lexicography, although it is at the same time a fact that specialised lexicographers also use a great part of the methodology that many terminologists consider a speciality of their discipline. In this field, the two disciplines have a lot in common.

However, when it comes to terminography, i.e. the presentation of the products of terminology in the form of different sorts of reference works, this is clearly the domain of lexicography. Whether or not we are dealing with the products of genetics, linguistics or terminology, when we have to present these products in lexicographic reference works, we are entering the special subject field of lexicography. That is why I consider terminography a subdiscipline of lexicography. And that is also the reason why I find it quite acceptable to review and criticise terminographic works on the basis of the principles developed by specialised lexicography.

\section{The users and their characteristics}

When you consider dictionaries as utility products made with the purpose of satisfying certain human needs, then two concepts are essential for lexicography as an independent science: the user and his/her needs. When a lexicographer conceives, produces or reviews a dictionary, he/she must always determine the corresponding or expected group of users and their needs. If this is not done, and that is unfortunately the case with many dictionaries, then lexicographic work cannot be done on a scientific basis. A concrete group of users can be homogeneous or heterogeneous. But in any case you must determine the characteristics of the users, first of all their language competence:

- Which language is their mother tongue?

- At what level have they mastered their mother tongue?

- At what level have they mastered a foreign language?

The above competencies are relevant for all monolingual and bilingual dictionaries, inclusive of LGP dictionaries. For a number of these dictionaries it is also important to know of the users' general cultural and encyclopaedic knowledge: 
- What is the level of their general cultural and encyclopaedic knowledge?

For specialised dictionaries you also have to know the users' competence in the respective subject field:

- At what level have they mastered the special subject field in question?

But this information is not enough. You must also know the users' LSP competence within the given subject field:

- At what level have they mastered the corresponding LSP in their mother tongue?

- At what level have they mastered the corresponding LSP in the foreign language?

All these competences have to do with what I call the basic or primary characteristics of the user group. But in order to produce a high quality dictionary that is user-friendly, the lexicographer must also know the users' general experience of dictionary use, which can be called their secondary characteristics.

\section{User situations}

However, these characteristics of the user group constitute only one aspect of what should be taken into account when conceiving a modern dictionary. You must also determine or know in which situations the user is going to use the dictionary and with what purpose.

Basically, there are two different kinds of general user situations. Firstly, the user consults the dictionary in order to facilitate an existing or future communication. Secondly, the user consults the dictionary in order to obtain knowledge about a special subject, or in very rare cases, in order to learn and study a foreign language. These two types of user situations can respectively be called communication-orientated and knowledge-orientated (Tarp 1998).

\section{User needs}

When a user consults a dictionary, this is done in order to achieve information that allows him/her to solve a concrete problem. The dictionary must be able to meet the needs that arise in such a situation. Often the needs are very simple and can be covered with only one or a few lexicographic data. In other situations the needs are very complex and can only be met with a combination of different sorts of lexicographic data. The user might need:

- information about the native language, 
- information about a foreign language,

- a comparison between the native and a foreign language,

- information about culture and the world in general,

- information about the special subject field,

- a comparison between the subject field in the native and foreign culture,

- information about the native LSP,

- information about the foreign LSP, and

- a comparison between the native and foreign LSP.

All these needs are primary user needs, because they are the needs that give birth to the consultation of the dictionary. There are, however, also other kinds of lexicographic user needs, which can be called the secondary user needs. These are the needs that arise when a dictionary is used:

- general information about lexicography and dictionary use, and

- information about the specific dictionary and how to use it.

In order to meet all these primary and secondary user needs, the lexicographer, when planning a dictionary, must know both the primary and the secondary characteristics of the user group. It is, of course, not the same to meet the LGP needs of a seven-year-old child who is still learning his/her mother tongue and the needs of an adult. It is not the same to meet the needs of a novice and a specialist within a given subject field. It is not the same to meet the needs of an experienced dictionary user and a person who is just consulting a dictionary for the first time.

\section{Lexicographic functions}

When you know the group of users, the users' characteristics, the user situations and the needs of the users, then you can determine the so-called lexicographic functions of the dictionary. A lexicographic function can be defined as "the endeavour and ability of the dictionary to cover the complex of needs that arise in the user in a particular user situation" (Tarp 1998).

The functions of a dictionary can be subdivided into communication-orientated and knowledge-orientated in correspondence with the respective user situations. The most important communication-orientated functions are:

- to assist the reception of texts in the native language,

- to assist the production of texts in the native language,

- to assist the reception of texts in a foreign language,

- to assist the production of texts in a foreign language,

- to assist the translation of texts from the native language into a foreign language, and 
- to assist the translation of texts from a foreign language into the native language.

The knowledge-orientated functions are:

- to provide general cultural and encyclopaedic information,

- to provide special information about the subject field or the discipline, and

- to provide information about the language (e.g. when studying a foreign language).

Of course, all this must be worked out in a more detailed way when you deal with a concrete dictionary. For instance, if the dictionary in question is treating a subject that has developed in a different way from country to country or from culture to culture, then the dictionary must also include functions in order to give the user information on the subject in both the user's own country or culture and in the foreign country or culture. This could for example be the case with legal dictionaries, where the legal systems differ very much from country to country, or from culture to culture. This leads to the following more detailed functions that are certainly very relevant for a great number of specialised dictionaries:

- to provide information about the legal system in the native country,

- to provide information about the legal system in the foreign country, and

- $\quad$ to compare the legal systems in the native and foreign countries.

Here I would like to add a comment. When we talk about specialised dictionaries, we of course expect that the users have a high native-LGP competence. You can also expect that a translator with a linguistic background has reached a high foreign-language competence (if that is not the case, he/she should not be working as a translator). But if the dictionary is also conceived to serve experts in the respective subject field, you cannot necessarily expect such a foreignLGP competence. Hence, in order to meet the needs of such users, you have to give more detailed general information about the foreign language. However, when it comes to LSP, many translators will most certainly lack the corresponding competence both in their mother tongue and the foreign language. And neither can the expert in the subject field be expected to have this LSP competence in both languages. There are many cases where experts do not have such a foreign-LSP competence. But there are also cases where they do not have it in their native language. That is for instance the case with many Danish geneticists who have only mastered the corresponding LSP in English. So you have to include more detailed information about the LSP in both languages in any case in order to satisfy the needs of both the translator and the 
subject-field expert. And when it comes to knowledge of the subject in question, then the translator is generally not expected to have this knowledge, part of which is necessary in order to produce a qualified translation. But neither will a semi-expert, e.g. a student of the subject field, have sufficient knowledge of the subject field in question, and he/she might use a dictionary in order to obtain this knowledge. And even the expert, who is supposed to know everything about the subject field, will in many cases in real life have to consult a dictionary in order to confirm his knowledge or the correct use of a concrete term. Thus, in order to meet the different needs of these users, the dictionary must include the necessary special information about the subject field.

As I have already mentioned, all these considerations must be worked out in a much more detailed way when preparing a concrete dictionary dedicated to a concrete group of users. However, I hope that I have showed that the only way to reach a scientific conclusion of what should be included in a dictionary is to base this conclusion on an analysis of the user, the user's characteristics, the user situations, the user needs and the corresponding lexicographic functions.

I have already quoted Wiegand's definition of the "genuine purpose" of a dictionary considered as a utility product. But on the basis of the above considerations, I would like to suggest an alternative definition, which I believe is much more operational when planning a concrete dictionary. This definition of the "genuine purpose" of a dictionary is as follows:

The dictionary covers this or that area and is conceived to assist users with these or those characteristics in this or that situation in order to solve problems of this or that sort (Tarp 1998).

\section{Priority and pragmatism}

The functions are the very essence of lexicography. The functions constitute the leading principle of all dictionaries. Everything in a dictionary is to a greater or lesser extent influenced by its respective functions. Neither the contents nor the form of a dictionary can be conceived without taking the functions into account. It is possible to outline an integrated model of a lexicographic reference work on the basis of the functions.

For this reason, it is not recommended to have an abstract discussion on whether or not certain lexicographic data or items should be included in dictionaries, for instance information about culture in LGP dictionaries and about professional jargon in specialised dictionaries. Such a discussion must, in order to be scientific, always be related to the respective function or functions of the dictionaries in question. Should, for example, irregular flexion forms be included as independent entries in a monolingual English learners' dictionary, i.e. the imperfect form "went" of the verb "go"? In a dictionary for text reception, it certainly should be done, because you cannot expect the users, espe- 
cially at beginners' level, to be able to relate this form to the entry "go". In a dictionary for text production, however, there would be no need to include "went" as an independent entry. In such a dictionary, it should figure as a morphological flexion form together with "gone" under the entry "go". On the other hand, should "went" and "gone" be included as flexion forms under the entry "go" in a learners' dictionary for text reception? Yes, this would be recommended as a means of identification that ensures the user that he/she has found the correct entry. This means that "went" and "gone" should be included as flexion forms under "go", both in learners' dictionaries for reception and for production, but for different reasons and with different purposes.

From the standpoint of user-orientated lexicographic theory, the best thing would always be to compile a dictionary with only one function and dedicated to only one type of user. In this way you will get the most accurate quality product designed to solve the special problems of a homogeneous group of users.

In practice, however, this is only possible in very few cases, normally when you are conceiving a LGP dictionary for a language that has a large number of speakers. And in specialised lexicography it is seldom the case. Thus, you have to combine various functions and a heterogeneous group of users. In order to do so, you have to analyse in detail what categories of lexicographic data are needed to cover each function for each different type of user. It is possible to combine all these categories in one and the same dictionary, but this frequently gives rise to problems and contradictions that make the dictionary less user-friendly, i.e. of lesser quality. And this is certainly not the objective of modern user-oriented lexicography.

Of course, as a means to solve this problem, you could omit certain data every time they create contradictions. But such a solution could also give rise to new problems, because it would result in a heterogeneous dictionary with a fluctuating quality where each type of user will sometimes be able to find what he/she is looking for and sometimes not. Another solution, which I prefer, and which is less pragmatic, would be to establish a ranking of functions and user types, giving first priority to some of them, second priority to others and third priority to still others. That means at least that you are sure that you are making a homogeneous quality product that meets the functions and serves the user types that you regard as most important for this particular dictionary. For the second and third categories of functions and user types, the dictionary may not be perfect, but it provides at least some kind of assistance to the users.

It is, however, not always possible to avoid pragmatism. Often you have to reduce the requirements of a planned dictionary due to financial limitations or the policy of the publishing house. But when you are pragmatic, it must not be in a pragmatic way. Pragmatism might be necessary in concrete cases, but it must be guided by theory in order to get the optimal results within the given limits. It is quite acceptable to say that it is not possible to meet all the demands of a linguistic translator (for instance, collocations) but that he/she is better off 
with a dictionary which at least provides equivalents than with no dictionary at all. But this should not lead to "lexicographic" products, as this article taken from an English-Danish specialised dictionary:

analyst analytiker, konsulent, planlægger

Text example 2: Dictionary article from L\&H (1992)

A native English-speaking translator who does not know anything about the subject field in question and the corresponding Danish LSP, would not know which of the three equivalents he/she should choose. Instead of helping the user, the dictionary is creating new problems that the user must solve before coming to a correct translation. In fact, the article is more dangerous than helpful, as the user has a 66 percent risk of choosing the wrong word. And these words are not at all synonymous: translated into English the three Danish words mean analyst (analytiker), adviser or consultant (konsulent) and planner (planlægger) respectively. The only native English speakers who could use this article would be those that already know the three Danish words and just need a reminder.

\section{What skills are needed?}

What skills are needed to conceive and produce a specialised dictionary? And what skills are needed to review it? These are basic and serious questions that have to do with the very quality of modern specialised lexicography.

Although lexicography is conceived as an independent science, it has, as already mentioned, a broad interdisciplinary vocation. Thus, a combination of several skills are often needed in order to produce a dictionary. And that is even more true when we are speaking about specialised dictionaries. In fact, I know only of one type of dictionary that can be produced with only one skill. That is a dictionary of lexicography where the lexicographer is a specialist in both dictionary making and the subject field in question. All other kinds of dictionaries need a combination of several skills. But what are these skills?

First of all, lexicographic skills. As I have argued in this paper, you cannot successfully engage in lexicographic work if you do it on the basis of other sciences or disciplines. You must have a specialised knowledge of lexicography. The role of the lexicographer is to conceive, plan, guide, direct and supervise the lexicographic project. If there is no person with special lexicographic skills, then the dictionary will not achieve the needed quality and will also often take much longer to finish, as the methods chosen would not always be the most suitable.

A second kind of skill needed in many lexicographic projects is linguistic knowledge. That applies to both LGP dictionaries and many specialised dic- 
tionaries where you have to give general information on language. In bilingual dictionaries, linguistic skills are needed in both languages.

A third kind of skill is general cultural and encyclopaedic knowledge. This is the case both with general knowledge-orientated dictionaries and with some general communication-orientated dictionaries where at least some general cultural and encyclopaedic information is necessary in order to assist the user.

When dealing with specialised dictionaries, a fourth category of skills is necessary. That is knowledge about the subject field in question. And if the dictionary is communication-orientated, then a fifth category is also needed, i.e. knowledge about the LSP in question in all the languages covered by the dictionary.

All these skills can very seldom be found in one and the same person. The lexicographer often has both linguistic and lexicographic skills. But even that is not always the case, especially where bilingual dictionaries are concerned. And when it comes to knowledge about the subject field, it is very seldom that the lexicographer also has that knowledge.

But what exactly is the role of the subject-field expert? For which concrete tasks is he/she needed? The expert is needed to make a classification or systematisation of the subject field in question, to select the texts for the dictionary corpus, to select entries, equivalents and collocations and to write definitions, explanations and a special introduction to the subject field, if any. But all these tasks cannot be accomplished by the expert alone, but must be carried out in close co-operation with and under the professional guidance of the lexicographer.

So the conclusion is that a lexicographic project must from the very start be seen as co-operation between various specialists within very different fields of knowledge. This requires a capacity for planning and co-operation with other specialists. If the lexicographic project is not conceived in this way, then the first step towards an inferior product has already been taken.

And the same applies to the review of a specialised lexicographic reference work. A review or criticism of a concrete dictionary cannot be done only by a lexicographer, a linguist or an expert, because then the review would easily be one-sided and would not reflect the many-sidedness of the dictionary. Only a lexicographer can judge the lexicographic quality of a given dictionary, only a linguist the linguistic quality and only a subject-field expert the corresponding subject-field quality. This means that to do a professional and qualified review of a given dictionary, this must also be undertaken co-operatively by specialists with different skills.

\section{Review}

What is the present situation concerning specialised dictionaries? The answer is very simple: there are pathetic, bad, average, good and excellent dictionaries, but the general situation is that the lexicographic quality leaves much to be de- 
sired. I will choose just two examples in order to illustrate what I mean. The first is an article from an English-German/German-English dictionary of business, commerce and finance:

bank 1. $n$ (bk) BANK Bank $f$, Bankinstitut $n t$, Geldinstitut $n t$, Kreditinstitut $n t ; 2$. vt BANK money einzahlen, zur Bank bringen; 3. vi with BANK ein Konto underhalten bei

Text example 3: Dictionary article from Dictionary of Business (1997)

This is a very typical dictionary article in a specialised dictionary. It possesses a number of good qualities. We are informed about the word class (although indirectly), about the gender and about the transitivity or intransitivity of a verb. A collocation is also given. But the article also creates some serious problems. Unfortunately, we are not informed for whom the dictionary is conceived, but a qualified guess would be both native German- and Englishspeaking translators, among others. They would surely have needed more collocations in order to produce a correct translation, especially the native English-speaking ones. This is, however, not the main problem. The article provides three equivalents that are not synonymous, and the native Englishspeaking user would find it very difficult to choose the right one. But even worse, we are not informed about the big differences between the British, American or South African banking systems and the German one. Without this important information, the translator could in a concrete situation very easily produce a wrong and very misleading translation. In this particular case, it would have been very beneficial if the dictionary had been conceived and produced on the basis of an analysis of the users and their needs.

The second article on which I will comment, is from an English-Spanish dictionary of gene technology. This dictionary was conceived to serve as a tool for a wide range of persons who want to know more about gene technology and "whose background may be in medicine, technology, pharmacy, biology and/or journalism", and, in addition, was also produced to assist students of gene technology in their studies and to serve translators translating texts from the field of gene technology. The dictionary is the result of a co-operation between lexicographers, Danish and Cuban experts in gene technology and specialists in the corresponding English and Spanish LSP. Let us look at an article from this dictionary, for instance "amino acid" (see text example 4).

This article, organised in paragraphs, contains an English entry and a Spanish equivalent, word class (although indirectly) and gender. It also includes an explanation together with an illustration in order to make it more understandable. Then there is a text example from an original document and a number of useful collocations. Finally, there are references to other entries and even to a 42 page systematic introduction to gene technology. In other articles in this dictionary there are also synonyms and antonyms. I think it is an excellent dic- 
Text example 4: Dictionary article from Kaufmann, Bergenholtz et al. (1998)

tionary that really meets the different needs of a very heterogeneous group of users.

\section{An irrelevant discussion}

At the beginning of this paper, I stressed that the understanding of lexicography as a subdiscipline of linguistics has had a number of negative consequences for theoretical and practical lexicography. There has been a pro- 
nounced tendency among many linguists who have practised lexicography at a theoretical or practical level to transfer their linguistic theories, principles and methods to lexicography. Of course, this is mainly a problem in LGP lexicography, which is not the topic of this paper. However, there is at least one discussion that must be considered to be foreign to specialised lexicography. That is the ongoing discussion on the difference between semantic and encyclopaedic items in dictionaries, e.g. in the definitions or explanations. There is a long tradition of discussion on this problem. And it has mainly been influenced by linguistics and, to a lesser degree, philosophy.

Haiman (1980) takes a philosophic point of departure and declares that dictionaries are encyclopaedias, thus making no distinction whatsoever between semantic and encyclopaedic knowledge. On the contrary, Landau (1984) makes such a distinction and declares that "dictionaries are about words and encyclopaedias about things". In this way, he excludes encyclopaedias from the world of dictionaries, but unfortunately he does not tell us how this distinction between words and things is to be made. The answer to this question can be found in Wiegand (1988 and 1994) who in a very detailed way argues how it is possible to distinguish between semantic and encyclopaedic items in lexicographic definitions. Rossenbeck (1994) doubts whether it is possible to make such a clear distinction as Wiegand proposes and Bergenholtz (1994 and 1998) declares outright that it is impossible.

I do not have the intention to participate in this discussion as a lexicographer. It might be interesting from the point of view of philosophy or linguistics whether or not a distinction can be made between semantic and encyclopaedic knowledge and whether or not such a distinction can be made in a very clear way. But from the point of view of modern lexicography, it is, at best, completely irrelevant. I say "at best", because a lot of people wasted a lot of time participating in this discussion instead of developing other aspects of lexicography. And I say "irrelevant", because from the point of view of user-orientated lexicography, the important concern is whether or not the definition or explanation meets the user's needs and not whether it can be analysed in different parts.

\section{A strange method}

The understanding of terminography as something different from specialised lexicography and exclusively related to terminology also creates big problems for the users. There is a tendency among a number of terminographers to transfer the principles and methods of terminology to lexicographic reference works. This makes them very user-unfriendly indeed. One such example is the Biotechnology Glossary that was published by the Commission of the European Communities in 1990 and prepared according to the principles of terminology. The Commission is one of the worldwide institutions that spends a considerable amount of money to produce lexicographic reference works. 
An introduction to the Biotechnology Glossary was written and signed by the Translation Service, Directorate for General and Linguistic Matters, Terminology Unit, in Brussels. In this introduction, the purpose of the glossary is clearly explained:

This glossary was originally conceived as an aid to translators faced with technical texts relating to biotechnology. The aim was to cover, with limited resources, a very wide field. (Biotechnology Glossary 1990: 1)

So the function of the glossary was the translation of biotechnological texts between the Community's official languages. And the user group was constituted as translators who are usually recruited among linguists or experts in various subject fields (but not necessarily biotechnology). Let us look at one article, or whatever you would call it, in order to study the result:

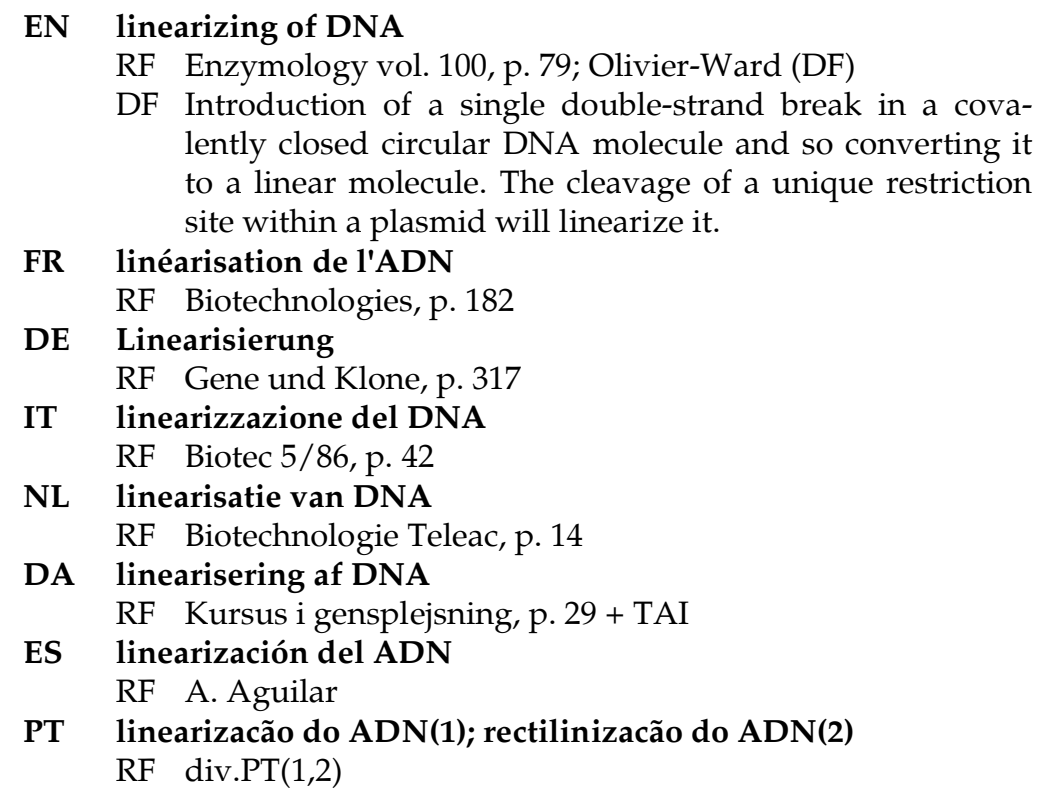

Text example 5: Article from Biotechnology Glossary (1990)

What catches the eye first of all is that there is no grammatical information. There is also no information on gender, morphology or collocations. This type of information, however, is essential when making a translation within a LSP unknown to the user. Of course, the shortage of collocations can be explained and even excused by the "limited resources" referred to, although the information on gender and morphology would have been relatively easy and cheap to 
produce. What cannot be excused, however, is that there is only a definition in one of the languages, i.e. English. In other cases there is again only a definition in French. And in still other cases there are definitions in several languages. In this way, the usefulness of the dictionary is automatically limited. tion:

This very strange principle is explained in the above-mentioned introduc-

Whilst the main purpose of this glossary was to provide equivalence in the Community's official languages, it was in some instances felt preferable to leave a concept without equivalent in a particular language rather than put forward a translation without original source. Explanations of the concepts used were also regarded as essential. Rather than attempt to establish definitions which would then have been translated into the various languages, we opted to include helpful examples (codes $\mathrm{DF}+\mathrm{NT}$ ) of the use of the terms taken from original documents, thereby enabling them to be considered from various standpoints. We hope that the results will prove useful to both translators and specialists. (Biotechnology Glossary 1990: 2)

This is, indeed, some kind of lexicographic masochism.

First of all, the translators who do not find any collocations or other grammatical information in their target language, and not even an equivalent, will hardly consider the glossary to be helpful and useful, as it does not meet their special needs in these cases.

Secondly, it might be a principle of part of terminology not to write definitions and instead go and look for them in original texts. This principle might be useful when the terminologists want to establish a knowledge database, but it does not serve any lexicographic purpose. The specialists referred to need a clear definition of the term and the translators, in many cases, also need a definition or explanation in order to produce a correct translation. But this dictionary does not help them, because when no "helpful examples" are found in "original documents", then it does not provide any explanations of the concepts, although they are "regarded as essential".

I do not want to discuss the principles of terminology. It is not my field. And I am perfectly aware that there are different opinions about this problem among terminologists. But I do not find it very wise to use these principles when you are working on a reference work, although it is disguised as a terminographical and not a lexicographic reference work. It is not the principles of an alien discipline that should decide how you make your reference work and what you include in it. This is only one example of the negative consequences of viewing terminography as something different from lexicography and then transferring the principles of terminology to a subject field where they do not belong. 


\section{Conclusion}

Lexicography is living very well - at least as a practice. But in a certain sense, lexicography is suffering from a severe disease. The problem is purely genetic. Lexicography has shared genes with linguistics, philosophy, terminology, etc. Therefore, the offspring has often been hybrids that cannot survive in the long run - and especially not in a modern world that increasingly demands quality. In order to survive, lexicography must opt for a user-orientated perspective. This is the only way to put it onto its own feet as an independent science and to ensure a new generation of lexicographic utility products that meet the needs of the modern dictionary user.

\section{Literature}

Bergenholtz, Henning. 1994. Faglige oplysninger i monolingvale betydningsordbøger. LexicoNordica $1: 13-26$

Bergenholtz, Henning. 1998. Das Schlaue Buch. Vermittlung von Informationen für textbezogene und textunabhängige Fragestellungen. Zettersten, A., J.E. Mogensen and V.H. Pedersen (Eds.). Symposium on Lexicography VIII. Proceedings of the Eighth International Symposium on Lexicography May 2-5, 1996 at the University of Copenhagen: 93-110. Tübingen: Max Niemeyer.

Bergenholtz, Henning, Jette Pedersen and Sven Tarp. 1994. Basic Issues in LSP Lexicography. Bergenholtz, H., A.L. Jakobsen, B. Maegaard, H. Mørk and P. Skyum-Nielsen (Eds.). Translating LSP Texts. OFT Symposium. Copenhagen Business School 11-12 April 1994: 151-187. Copenhagen: OFT-projektet, Copenhagen Business School.

Bergenholtz, Henning and Sven Tarp. 1995. Manual of Specialised Lexicography. The Preparation of Specialised Dictionaries. Amsterdam: Benjamins.

Biotechnology Glossary (1990) = Biotechnology Glossary. Commission of the European Community. London/New York: Elsevier Applied Science.

Dictionary of Business (1997) = German Dictionary of Business, Commerce and Finance. Wörterbuch für Wirtschaft, Handel und Finanzen English. London/New York: Routledge.

Glick, David M. 1997. Glossary of Biochemistry and Molecular Biology. Revised Edition. London/ Miami: Portland Press.

Haiman, John. 1980. Dictionaries and Encyclopaedias. Lingua 50: 329-357.

Kaufmann, Bergenholtz et al. (1998) = Kaufmann, Uffe and Henning Bergenholtz in cooperation with B. Stumman, S. Tarp, L. de la Rosa Marabet, N. la Serna Torres and G. la Serna Miranda. 1998. Encyclopedic Dictionary of Gene Technology. English-Spanish. Toronto: Lugus.

Landau, Sidney. 1984. Dictionaries: The Art and Craft of Lexicography. New York: Scribner Press.

L\&H (1992) = LEH fagordbog, engelsk-dansk. Copenhagen: L\&H Fagordbøger.

Rossenbeck, Klaus. 1994. Enzyklopädische Information im zweisprachigen Fachwörterbuch. Bergenholtz, Henning and Buchard Schaeder (Eds.). Fachlexikographie. Fachwissen und seine Repräsentation in Wörterbüchern: 133-159. Tübingen: Gunter Narr.

Tarp, Sven. 1992. Encyklopædiske oplysninger i tosprogede tekniske ordbøger. Ruth Vatvedt Fjeld (Ed.). Nordiske studier i leksikografi. Rapport fra Konferanse om leksikografi i Norden 28.-31. mai 1991: 522-531. Oslo: Nordisk forening for leksikografi. 
Tarp, Sven. 1994. Funktionen in Fachwörterbüchern. Bergenholtz, Henning and Buchard Schaeder (Eds.). Fachlexikographie. Fachwissen und seine Repräsentation in Wörterbüchern: 229-246. Tübingen: Gunter Narr.

Tarp, Sven. 1995. Wörterbuchfunktionen: Utopische und realistische Vorschläge für die bilinguale Lexikographie. Wiegand, H.E. (Ed.). Studien zur zweisprachigen Lexikographie mit Deutsch II: 17-51. Hildesheim/New York: Olms.

Tarp, Sven. 1998. Leksikografien på egne ben. Fordelingsstrukturer og byggedele i et brugerorienteret perspektiv. Hermes 21: 121-137.

Wiegand, Herbert Ernst. 1988. Was eigentlich ist Fachlexikographie? Mit Hinweisen zum Verhältnis von sprachlichem und enzyklopädischem Wissen. Munske, H.H., et al. (Eds.). Deutscher Wortschatz. Lexikologische Studien. Ludwig Erich Schmitt zum 80. Geburtstag von seinen Marburger Schülern: 729-790. Berlin/New York: Walter de Gruyter.

Wiegand, Herbert Ernst. 1994. Zur Unterscheidung von semantischen und enzyklopädischen Daten in Fachwörterbüchern. Bergenholtz, Henning and Buchard Schaeder (Eds.). Fachlexikographie. Fachwissen und seine Repräsentation in Wörterbüchern: 103-132. Tübingen: Gunter Narr. 